\title{
SOME ASPECTS OF CULTIVATION AND UTILIZATION OF WAXY MAIZE (Zea mays L. ssp. ceratina)
}

\author{
${ }^{1}$ Agnieszka Klimek-Kopyra, ${ }^{1}$ Aleksander Szmigiel, \\ ${ }^{1}$ Tadeusz Zając, ${ }^{2}$ Agnieszka Kidacka
}

\author{
${ }^{1}$ Institute of Plant Production, Department of Plant Production, University of Agriculture in Kraków \\ Mickiewicza 21, 31-120 Kraków, Poland \\ ${ }^{2}$ Małopolska Hodowla Roślin HBP-Sp.zo.o, Zbożowa 4, 30-002 Kraków. \\ e-mail:aklimek@ur.krakow.pl
}

Received: 27.04.2012

\section{Abstract}

This paper is a review of available literature on Zea mays L.ssp.ceratina. It contains information on the origin, cultivation and utilization of waxy maize in the world and can be a contribution to the development of new research on maize cultivation and starch processing technology.

Maize, as an old and economically important cereal, played an enormous role in the ancient civilisations of the New World. Among the maize subspecies compared, Z. mays ssp. indurata and Z. mays ssp. indentata are now the most important in Poland. The subspecies Z. mays ssp. saccharata has a marginal role, while $Z$. mays ssp. ceratina has not been hitherto cultivated. Decisions to introduce the subspecies Z. mays ssp. ceratina into cultivation are based on different grounds, taking into account both agro-climatic conditions and industrial uses of grain processing products. The growing demand for maize grain, stimulated by the increased demand for maize starch and oil in the global market as raw materials that are important in food production, is an impulse for the development of agrobiological research. The development of the starch industry, associated with the demand for industrial starch, will probably contribute to increased interest in this subspecies in Central Europe, also including Poland. Waxy maize grain can be a major ingredient of high-energy feeds for livestock, replacing in this role the type of maize that has been grown for this purpose until now.

A great advantage of waxy maize is its specific structure of starch, due to its unique and high amylopectin content (95-98\%), which creates unlimited possibilities of industrial use. Currently, waxy maize acreage in Europe does not exceed $2 \%$ of the maize crop area in this continent.

Key words: Zea mays L. ssp. ceratina, origin, cultivation, grain properties, chemical composition, industrial use, animal feeds.

\section{INTRODUCTION}

This paper is a review. In our region, there is marginal interest in the cultivation and utilization of Zea mays ssp. ceratina grain. Numerous data presented in particular sections of this paper relate to the origin, history of cultivation, grain properties, agronomy as well as the use of maize raw material in industry and for animal feed production.

Maize played an enormous role in the ancient civilisations of the New World from the oldest times. This cereal was grown across the whole American continent down to the present Argentina and Chile. It appeared quite soon afterwards in Europe, Africa and Asia (N ow iński , 1970). Maize reached Poland much later (19th century) and was known under the name of "Turkish wheat" (F e lis i a k, 1987). In the regions of Wielkopolska (Greater Poland) and Małopolska (Lesser Poland), green maize was originally harvested, whereas grain maize was grown in gardens. A new era in maize cultivation began after Mikołowski-Pomorski, Górski and Golonka had introduced new more productive varieties. However, a true breakthrough in maize breeding occurred in the middle of the 1950's as a result of the use of the heterosis effect ( $\mathrm{G}$ ąsiorowski, 2005, 2006, 2008). Currently, maize is one of the three most important agricultural plant species in the world, alongside wheat and rice. As an annual plant, it is mostly grown for grain which is used for the production of flour, animal feed and ethanol. Grain production per unit area has been growing systematically; it increased from $1.9 \mathrm{t} \times \mathrm{ha}^{-1}$ in 1960 up to $5.1 \mathrm{t} \times$ ha $^{-1}$ in 2008 . A major part of maize grain is used as livestock feed 
in the form of cracked maize but, as reported by $\mathrm{No}$ c e k and T a m ming a (1991), there are limitations in using maize for livestock feeding due to its low protein and vitamin content.

Among the subpsecies compared, Zea mays ssp. indurata and Z. mays ssp. indentata are of the greatest importance (M i c hal s k i, 1997). The significance of the subspecies Zea mays ssp. saccharata in growing maize is much smaller, while Z.mays ssp. ceratina has a marginal role (C o 11 i n s , 1909, 1920; W a 1 ig ó r a et al. 1998). The first reports about the occurrence and cultivation of waxy maize in China come from 1909 (Collin s, 1909).

A decision to grow a particular maize subspecies involves many aspects and is based on specific climatic and soil conditions, tradition and consumer needs as well as on the market for maize raw material. Sweet corn is more and more frequently promoted as a vegetable product and also as raw material for the processing industry (W a li g ó $\mathrm{r}$ a et al. 1998). In Poland sweet corn is grown on an area of not more than 4,000 ha, which is associated with its low consumption, since sweet corn consumption remains at a level of $0.5 \mathrm{~kg} /$ person (W a lig ó r a , 2006). Waxy maize (Z. mays ssp. ceratina) is even less popular in Europe; it differs from other subspecies by the unique structure of its starch due to a reduced percentage of the amylose fraction and an increased percentage of amylopectin. In nutritional terms, the composition of the waxy maize grain is similar to that of other subspecies of $Z$. mays, which is associated with, among others, a low amount of protein (9\%) ( $\mathrm{Z}$ a r a te et al. 2004). 200,000 tonnes of waxy maize grain is now produced in Europe, mainly in France. In this country, the average annual acreage is 30,000 ha in the southern and northern regions, out of the total crop area of 1.5 million hectares (B o c k et al. 2002). Waxy maize production in Europe accounts for not more than $2 \%$ of the total maize crop area and the utilization of waxy maize depends on the quality of raw material obtained. Waxy maize grain is thought to be an interesting alternative to hybrid maize if it is used for industrial purposes, i.e. the recovery of starch and its processing into particular substances or for modified starch production. The grain of this species is mostly intended for industrial use, though it can also be used as animal fodder to feed poultry ( $M$ u s s e h 1, 1944; D in n et al. 1982), pigs (J ohnston and Anderson, 1992; Ertl and Dale, 1997), and cattle (Akay and Jackson, 2001). However, the current scale of waxy maize cultivation is relatively small, which nowadays is translated into its small economic importance.

It is thought that total maize grain production will be one of the largest in Europe in the near future due to the developing starch and biofuel industries.
Assuming that the agricultural policy of the below mentioned states does not change until 2020, maize grain production in the USA will be 297 million tonnes, 295 million tonnes in China, and 54 million tonnes in Brazil, whereas the Eastern Europe countries will reach a total production of 40 million tonnes.

The need, widespread in recent years, to improve the nutritional values of maize grain as a major cereal in Asian countries has not resulted in an increased amount of protein in the grain composition. Hence, common protein deficiency and protein-calorie malnutrition in people can be observed in many regions in the world where maize is the main source of food. Attempts have now been undertaken in plant breeding to improve maize varieties in terms of their quality related to a higher percentage of protein in the grain, including endogenous amino acids - lysine and tryptophan (O $\mathrm{r}$ et al. 1993; D a n g, 2010). In Asia the cultivation of waxy maize is promoted to increase human food production, while the leading subspecies producing 'flint' or 'dent' kernels are now the primary source of livestock feed (silage and cracked maize). Its high carbohydrate content and relatively long storage period predispose it for such purposes.

\section{THE ORIGIN AND CHARACTERISTICS OF WAXY MAIZE}

The original form of waxy maize had erect leaves growing from the upper nodes, while the lower leaves were spread and drooping (Collins, 1909). Moreover, the leaves up to the $4^{\text {th }}-5^{\text {th }}$ leaf from the bottom grew on the same side of the plant. The above-mentioned author stressed high drought resistance of maize, in particular at the flowering stage, and waxy maize was positively distinguished from other Z. mays subspecies by this trait.

The basis of phenotypic selection of maize was applied as early as 1900 in China, which is described by Coll in s (1909). The characteristics of waxy maize given by Collins were based on an analysis of the morphological characters associated with plant growth. It was discovered much later, as late as the 1990's, that the characteristic features of the endosperm in maize were controlled by a single recessive gene found in chromosome 9 which was described and named waxy $(w x)$ or china waxy $(w x-c)$, due to the region of its origin. Co e et al. (1988) described the characteristic phenotypic features of the grain as marbled, opaque and hard. The endosperm of waxy maize develops only branched starch molecules (amylopectin) which are devoid of the linear fraction. The next unique feature of starch in this subspecies is the expansion reaction taking place as a result of treatment with iodine solution (W e a th e rw a x , 1922). When treated with potassium iodide, amylopectin of waxy maize stains 
red and brown, whereas normal starch turns blue and black. Waxy maize from the area of Argentina (wx-a), described by Andrés and B ascialli (1941), is known to produce grains containing a small amount of amylose $(<5 \%)$, which gives an immediate reaction with iodine. Other mutants found within this subspecies are similar to those previously described (B e a r, 1944; N e 1 s o n , 1968).

During the period from 1930 to 1990, waxy maize was grown sporadically for production purposes and researchers concentrated more on breeding experiments. In the 1940's at the Agricultural Experimental Station in Iowa (USA), further and, at the same time, important properties of amylopectin of waxy maize were discovered which are similar to those found in tapioca (Manihot utilissima) ( $\mathrm{S} \mathrm{ch} \mathrm{op} \mathrm{me} \mathrm{ye} \mathrm{r} \mathrm{et} \mathrm{al.}$ 1943). Due to the fact that it was not possible to import tapioca from eastern Asia during World War II, there was a breakthrough in the use of waxy maize starch for industrial purposes. The U.S. government launched a special research programme designed to implement the starch of this subspecies into different industries. Thus, research was carried out in the state of Iowa which was aimed at improving the chemical properties of maize grain in order to process this grain only for industrial purposes. Currently, breeding programmes are still being developed in the USA and they are designed to improve the genetic line of waxy maize with regard to its yield-enhancing traits. Fe r g a s o n (2001) indicates that waxy maize varieties are now equal in yield to 'dent' field corn, and average variations in yield do not exceed $5 \%$. But a real breakthrough in the process of selection of new varieties over the last 20 years has been observed in China. In this country, scientists have undertaken a number of studies to improve grain quality, including an increase in embryo weight, in order to enhance the processing capacity of the vegetable oil and starch industries (D i n g et al. 2006). As a result of that, both high oil corn (HOC) and high oil waxy corn (HOWC) have been bred (Table 1).

Table 1

The chemical composition (\%) of some normal and waxy corn subspecies and varieties

\begin{tabular}{lcccc}
\hline \multicolumn{1}{c}{ Chemical component } & Normal corn & High oil corn & Waxy corn & High oil waxy corn \\
\hline Dry matter & 85.92 & 87.06 & 89.31 & 89.43 \\
Crude oil & 3.66 & 7.51 & 4.62 & 8.22 \\
Crude protein & 7.37 & 8.33 & 8.97 & 9.77 \\
Starch & 62.9 & - & 68.5 & - \\
ME Kcal/kg & 3314 & 3540 & 3494 & 3650 \\
\hline
\end{tabular}

Source: Akay and Jackson, 2001; Zarate et al. 2004.

Starch, as a complex carbohydrate, belongs to the group of the most important plant products, extremely essential in animal and human nutrition (B u r rell, 2003). Cereal grains are the main source of starch and partially it can be also obtained from roots and tubers. It is estimated that every year cereal plants can produce 2050 million tonnes of starch, whereas roots and tubers supply only 679 million tonnes of this component (T e s t e r and $\mathrm{K}$ a r k a l a s , 2001). In developed countries, starch supplies on average $35 \%$ of the daily caloric requirement for humans. Maize, rice and wheat grain as well as potato tubers are the main plant sources of this component. In many areas of the world, in particular in the continent of Africa and in the Far East, starch supplied as food from rice grain currently accounts for up to $80 \%$ of the daily caloric requirement for humans.

One should stress the fact that starch has been used for food and non-food purposes for centuries, since already the ancient Egyptians and later Romans used this component as an adhesive (glue), while the Greeks used it as a medicine (Te ste r and $\mathrm{Karkalas}$, 2002; B u r re 11, 2003). In chemical terms, starch is composed of amylose and amylopectin. Amylose has long -1,4 chains linking the glucose residues and a relatively small number of branched $-1,6$ bonds, whereas amylopectin contains a high number of branched $-1,6$ bonds and a small number of branched $-1,4$ bonds linking the glucose residues. These two molecules produce the semi-crystalline form of starch (B a nk s and Muir, 1980; Ka in u ma, 1988). The average size of starch grains ranges from 0.5 to 170 $\mu \mathrm{m}$ (Golachowski, 1998). Among cereal plants, normal maize has the largest average size of starch grains $(5-25 \mu \mathrm{m})$, whereas in the kernel of waxy maize the average size of starch grains is in the range of 4-28 $\mu \mathrm{m}$ (Lewandowicz and Mączyński, 1990). The size of starch grain is of major importance for industrial use, since it determines the physico-chemical properties of a particular starch ( $\mathrm{R} \mathrm{a} \mathrm{t} \mathrm{u} \mathrm{s} \mathrm{z} \mathrm{n} \mathrm{i} \mathrm{a} \mathrm{k}$ and $\mathrm{Ku} \mathrm{b}$ a s, 2007). Maltodextrin and starch are an important source of energy for small children due to the low propensity of this type of food to fermentation. It is estimated that about $70 \%$ of food products now contain corn syrup in its composition (Teste $r$ and 
Karka la s, 2002; B u rre11, 2003). Waxy maize starch is an important ingredient in the preparation of various meat products and ready-made meat dishes.

\section{THE EFFECT OF CULTIVATION ON BIOLOGICAL CHARACTERS AND YIELD}

The growing interest in waxy maize cultivation across the world, due to the ever higher demand for starch in the food and processing industries, has contributed to the development of agronomic research. Fertilization and seeding rate are the factors that limit waxy maize yield. Depending on the plant growth stage, the absorptive ability of cultivars and habitat conditions, different fertilization rates can be used in growing waxy maize (W e ir et al. 1996). P i e k i e lek and Fox (1992) report that the maximum daily nitrogen intake 30-45 days after emergence (at silking stage) is $4.43 \mathrm{~kg} \times \mathrm{ha}^{-1} \mathrm{~d}^{-1}$. B oonlertnirun et al. (2010a) compared three waxy maize cultivars and found the average plant height to be $160 \mathrm{~cm}$. These authors showed that fertilization rates did not differentiate the growth of these cultivars, but the rate of nitrogen at a level of $250 \mathrm{~kg} \mathrm{~N} \times \mathrm{ha}^{-1}$ was economically justified. Different results were obtained in the study of Boonlertnirun et al. (2008) who found that the application of increasing rates of nitrogen resulted in significant differences in plant dry weight per unit area. These authors proved that significantly higher dry weight per plant $\left(90 \mathrm{~g} \times\right.$ plant $\left.^{-1}\right)$ could be obtained after the application of nitrogen at a rate from 75 to $225 \mathrm{~kg} \times \mathrm{ha}^{-1}$, but the higher rates were not economically justified. Such results were also observed in other cereal plants in which an increase in nitrogen fertilization also affected the growth of the aerial parts ( $\mathrm{B}$ a l a subramanian and Singh, 1982).
Moreover, B oonlertnirun et al. (2010b) showed that nitrogen fertilization of waxy maize at a rate of 75-225 $\mathrm{kg} \mathrm{N} \times$ ha had a highly significant effect on increasing leaf area of waxy maize plants. In this study, the maximum leaf area per plant was found to be at a level of $4,253 \mathrm{~cm}^{2}$, while the minimum value of this parameter was $1,640 \mathrm{~cm}^{2} \times$ plant $^{-1}$.

Oiken et al. (1998) and A m a n y et al. (2006) showed that an increase in nitrogen fertilization had a significant effect on maize grain yield, but the method of application of this element is also important. The authors of this study indicate that the slow-release system for nitrogen forms is of greater importance due to plant physiology. Higher rates of nitrogen, in the range of 300-480 kg $\times$ ha $^{-1}$, have been tested in China. $\mathrm{X}$ i e (2006) found that waxy maize responded well to increased nitrogen fertilization up to a level of $420 \mathrm{~kg}$ $\times$ ha $^{-1}$, but the best grain, in terms of its quality, could be obtained at the lower rates, up to $360 \mathrm{~kg} \times \mathrm{ha}^{-1}$. Similar results were obtained under field conditions by B oonlertnirun et al. (2010a) from the Thai Agricultural University who showed the maximum rates of nitrogen fertilization to be in the range of $150-300 \mathrm{~kg} \times \mathrm{ha}^{-1}$. The above quoted references demonstrate that it is necessary to use fertilization rates of 250 up to even $400 \mathrm{~kg} \mathrm{~N}$. Under European conditions, nitrogen rates applied in maize crops are in the range of 90-180 kg N $\times$ ha $^{-1}$ (K r u c ze k, 1983; B or ow i e c ki, 1988; F o t y m a, 1994). In other regions of the world, the range of rates applied varies and depends on climatic and soil conditions (Table 2). The presented results of different field experiments show that the highest amount of nitrogen fertilizers is used in Asia and Argentina, while the lowest one in Europe and in the USA. It can be presumed that under the conditions of Poland waxy maize will have similar nutritional requirements.

Table 2

Waxy maize cultivation regions and nitrogen rates applied.

\begin{tabular}{lcl}
\hline \multicolumn{1}{c}{ Region } & Rate $\mathrm{N}\left(\mathrm{kg} \times \mathrm{ha}^{-1}\right)$ & \multicolumn{1}{c}{ Source } \\
\hline Italy & $150-240$ & B landino and Reyneri, 2007 \\
Denmark & 140 & Eggum et al. 1985 \\
Thailand & 300 & B o onlertnirun et al. 2010a \\
China & $250-420$ & Xie, 2006 \\
USA & $140-180$ & B rookes and B arfoot, 2004 \\
Argentina & $175-300$ & V alero et al. 2005 \\
\hline
\end{tabular}

Chen et al. (2003) found waxy maize grain yield to be significantly dependent not only on nitrogen fertilization, but they claimed that plant density was also important. The results of their study showed that higher than average grain yield was obtained at a plant density of 60,000 plants per hectare and 
a fertilization rate of $225.5 \mathrm{~kg} \mathrm{~N} \times \mathrm{ha}^{-1}$. Similar results were obtained by $\mathrm{Z}$ h a o et al. (2009) who emphasize that maximum foliage parameters, as expressed by LAD, LAI and dry weight per ha, could be obtained in a crop with a density of 60,000 plants $\times \mathrm{ha}^{-1}$. J in et al. (2010) report that, in productive terms, the most appropriate plant density is 90,000 plants $\times \mathrm{ha}^{-1}$ and above this value grain yield declines.

T a n g et al. (2009) compared the proportion of particular components of the above-ground biomass of normal and waxy maize during growth. These authors confirmed the earlier reports of Tole$\mathrm{ra}$ and Sundstol (1999) which show that during vegetative growth the amount of dry matter changes between different plant parts. At fill grain (milk stage), the stem part had the highest percentage in total shoot dry weight, while flag leaves and sheathing leaves of cobs had a smaller percentage. It was also interesting that during growth the percentage of leaves (leaf blade and leaf sheath) of Z. mays ssp. ceratina in total shoot weight increased, while the percentage of stems decreased. In waxy maize, the percentages of the investigated fractions were as follows: leaf blades (LB)-25.9\%; leaf sheaths (LS)-14\%; stem (ST)41.1\%; husks (HK)-19\%; and they were similar to the proportions of these fractions in field corn, for which the respective values were the following: LB-27.2; LS-14.3; ST-36.7; HK-21.8\%. The present study showed significant differences in total protein content. The protein content $\left(\mathrm{g} \times \mathrm{kg}^{-1} \mathrm{DW}\right)$ in the above-ground mass of waxy maize was proved to be significantly higher compared to field corn, since in the plant parts in question its values were as follows: LB-160; LS55; ST-62; HK-50, whereas in the conventional form: LB-56; LS-50; ST-53; HK-50. The results for crude fibre content were opposite, which is confirmed by A k a y and J ackson (2001). It is stressed that the higher protein content and lower fibre content in animal feed result in better digestibility of waxy maize silage (M u staf a et al. 2008). However, T ang et al. $(2008,2009)$ think that the higher nitrogen content in waxy maize can result from the higher sorptive capacity of the root system, which is translated into an increase in the amount of protein in leaves and stems.

Sowing date has a significant effect on grain quality. Studying the effect of sowing date (in the period from the $3^{\text {rd }}$ decade of April until the $2^{\text {nd }}$ decade of May) on maize yield, Li u et al. (2009) showed significant differences in the quality of harvested grain. These authors found that the late sowing date (the $2^{\text {nd }}$ decade of May) negatively influenced the amount of starch, protein and oil obtained. The decrease in the quantitative and qualitative parameters of grain yield was associated with lower total rainfall available to the plants during growth.

\section{WAXY MAIZE AS INDUSTRIAL RAW MATERIAL}

Waxy maize was originally used mainly for industrial production and only to a small extent for food production (Moore et al. 1984; H a w t o n et al. 1996). J u ge n hei mer (1976) set out the scope of industrial use of waxy maize as more important for economic development. Among many uses of maize grain, this author mentioned the use of maize starch in the vegetable oil, chemical and textile industries as well as for the production of plastics. In Asia, there is currently a growing interest in waxy maize for the food industry and for the production of biogas intended for nitrogen fertilizer production ( $\mathrm{T}$ a $\mathrm{ng}$ et al. 2011).

The production of biomass in Z. mays ssp. ceratina is controlled by a single recessive gene, therefore grain quality is determined primarily by the genetic purity of seed material. It is thought that maize grain production on an industrial scale requires the observance of the principles related to spatial isolation of crops in order to protect them against self-crossing of various subspecies (B rink and $\mathrm{Macgi} l \mathrm{ln}$ ajy, 1924). Furthermore, waxy maize grain for industrial purposes should have high quality as well as large and well-formed kernels of full health and purity (99\%). Grain uniformity is also important, including its size and colour. In North America, waxy maize grain production is strictly controlled and contracted in terms of its intended use for the milling and starch industries. Starch extraction from maize grain is the first stage towards versatile modification. Starch modification is used in the food, confectionery, and milk industries as well as for storage of food products (M o ore et al. 1984). The paper industry also owes its great progress to the implementation of modified starch of $Z$. mays ssp. ceratina. Waxy maize starch has contributed to an improvement in the process of binding of paper material, which has had an effect on printing quality. Modified starch has also contributed to the development of the textile industry (K i r b y, 1986). Starch obtained from waxy maize is used very frequently in starch-producing plants, as a result of wet grinding. Grains used for this purpose should contain a large amount of starch, which is associated with the absence of damage of the cell structure during harvest. Slight differences in the amount of starch can affect the quality of laundry starch obtained. The unique properties of starch, compared to flint or dent maize, are an attribute for its production and processing.

Most of natural starch obtained has specific and limiting physical and chemical properties, which gives rise to a number of technological problems. Industrial utilization of starch is associated with the need to carry out many expensive repression processes in order to give proper physical properties to starch. Waxy maize 
belongs to the class of special purpose maize, characterized by a unique structure of starch, which creates enormous possibilities for its modification ( $\mathrm{Ferg}$ a s o n, 2001). Chemical modifications include crosslinking associated with the introduction of additional cross links into the chemical structure of starch, the effect of which is greater resistance to thermal conditions, $\mathrm{pH}$ ( $\mathrm{Kry}$ s i ńs k a et al. 2008). Such modified starch is used to improve the texture of pastas and fruit fillings for cakes (W a łkowski and Lewandowicz, 2004). On the other hand, double modified starch is commonly used for the production of sauces, tinned vegetables and meat, frozen products and desserts (L e s z c z y ń s k i, 2006). In his paper, Y o u n g (1984) presents as many as 30 processing areas in which this raw material can be used. Waxy maize grain is used in the food industry (M o o r e et al. 1984; L a n g m a n, 1986), paper industry (M a her and Cremer, 1993), and textile industry (K i r b y , 1986) as well as for other industrial purposes (R o hwer and Kle m, 1984).

\section{THE USE OF WAXY MAIZE AS ANIMAL FEED}

The dynamic development of livestock farming and the creation of new waxy maize varieties (in the USA and in Asia) have increased the potential possibilities of using this species for animal feed purposes. Johnston and Anders on (1992) proved that the chemical composition of the grain of waxy maize could contribute to greater use of this fodder material in feeding slaughter cattle. Schroeder et al. (1996) indicate the fact that waxy maize grain is as good as normal maize grain in feeding dairy cattle. However, the proportion of grain in livestock feed is of great importance for the use of waxy maize. The complete replacement of dent maize with waxy maize did not result in significant differences in the amount of milk obtained and in changes in its composition. As a result of applying a 50\% proportion of each type of maize grain, a decline in the amount of milk fat was recorded, which may prove the adverse interaction in the use of these two types of starch by an animal. According to
H unting to n (1997), variation in nutritional needs of cattle is an attribute for changes in the composition of the endosperm in maize. B a n k s and M u i r (1980) as well as B rown et al. (2001) showed that amylopectin accounted for nearly $95 \%$ of starch in waxy maize, whereas in normal dent maize the percentage of amylopectin is at a level of $73 \%$. Additionally, starch granules of waxy maize have higher hydrolytic ability, hence fodder from waxy maize was expected to have higher digestibility (K i m ura and R obyt, 1995). Digestibility evaluated for waxy maize can change the character of fermentation in the rumen ( $\mathrm{B} \mathrm{ram}$ a $\mathrm{n}$ et al. 1973; Streeter et al. 1991; Kotarski et al. 1992) and also affect the quality and quantity of milk (Nocek and Tramminga, 1991). Kotarski et al. (1992) report that starch from waxy maize is more digestible and its structure with protein has a greater ability to degrade during technological processes. Maize grain is also a basic source of energy in poultry feeding. Co 11 i n s et al. (2003) carried out a comparative study on the effect of the properties of grain of two maize subspecies on the weight of poultry meat and its quality. The authors proved that feeding young chicks with waxy maize grain was more efficient than feeding them with traditional dent maize. It is worth paying attention that better digestibility of starch for dairy cattle is not an advantage at all, since digestible starch is sought as far as the duodenum (by-pass starch).

T a n g et al. (2009) conclude that the nutritional value of waxy maize is dependent not only on climatic conditions and proper agricultural practices, but also on the morphotype. Tolera and Sundstol (1999) as well as T a n g et al. (2008) report that total protein content was significantly higher in the leaves, and lower in the stems. Moreover, the nutritional value of waxy maize is also affected by plant growth stage and sowing date. A delayed date of maize harvest had an effect on a lower weight of leaves and stems, a lower amount of protein and phosphorus as well as a higher quantity of fibre. Conventional maize varieties had a lower amount of total protein and a higher amount of fibre in the kernel compared to sweet, waxy and field corn (T o le ra and S u nd s to 1, 1999).

Table 3

Nutrient content (\%) in grain of various subspecies and varietes of Zea mays L.

\begin{tabular}{lcccccc}
\hline \multicolumn{1}{c}{ Maize subspecies } & Protein & Oil & Fibre & Starch & Yield $\mathrm{t} \times$ ha $^{-1}$ & Source \\
\hline Waxy & 9.1 & 4.5 & 2.2 & 73.2 & 9.33 & Fergason, 2001 \\
Sweet & 3.3 & 1.9 & 1.4 & 5.7 & 4.00 & Waligóra, 1998 \\
Normal traditional variety & 9.9 & 4.6 & 2.1 & 71.6 & 11.2 & Aleksander, 1988 \\
Normal high-oil variety & 8.3 & 7.6 & 2.9 & 67.9 & 11.9 & Aleksander, 1988 \\
Normal high-protein variety & 12 & 5.0 & 2.1 & 58 & 5.97 & Vasal, 2001 \\
\hline
\end{tabular}


Waxy maize contains an increased amount of protein and oil, but less than the high-oil variety. Most of these differences are a result of changes in the size of the embryo in the grain, up to the endosperm.

\section{SUMMARY}

Based on FAO forecasts, it is expected that there will be a significant global increase in demand for industrial maize grain over the next 20 years. The global demand for maize grain results from the higher demand for starch in the world market and to a lesser extent from the demand for grain for consumption, which can be observed in particular in the USA and Asia. In Europe the higher demand for starch will be met through the increased proportion of high-starch varieties in the general structure of maize crops. However, starch from grain has limited modification properties due to its biochemical structure. A result of this is the extension of technological processes designed to give proper physico-chemical properties to starch. Waxy maize is characterized by a unique structure of starch, which allows a simplified process of its modification and gives wide possibilities of industrial use. New sources of variation are now sought, relating to increased embryo weight in the kernel, which will increase oil yield per hectare. An increased proportion of glassy endosperm in the grain will be translated into a significant increase in protein, which is important for the milling industry. A higher percentage of the floury endosperm fraction in the kernel will contribute to increased starch content, essential for ethanol production. For these reasons, waxy maize has become an important source of starch in the region of Asia, America and Africa, but it is still marginalized in Europe. In Poland relevant research has not been hitherto undertaken and varieties of this subspecies have not been introduced into cultivation. Therefore, an urgent research task is to evaluate, under domestic conditions, varieties of $Z$. mays ssp ceratina as well as their yield and chemical composition. It can be presumed that the development of the starch industry, associated with the demand for industrial starch, will contribute in the near future to ncreased interest in waxy maize in our country. Waxy maize grain, which is an interesting alternative for the starch industry, can compete with normal maize grain and contribute to the development of the cultivation of this subspecies.

\section{Acknowledgements}

Research supported by the Ministry of Science and Higher Education of Poland as the part of statutory activities of Department of Plant Production University of Agriculture in Cracow.

\section{REFERENCES}

Akay V., Jackson J.A.J. 2001. Effects of NutriDense and waxy maize hybrids on the rumen fermentation, digestibility and lactational performance of dairy cows. J. Dairy Sci. 84, 1698-1706.

A lex a nder D.E. 1988. Breeding special nutritional and industrial types. 869-880. [In:] G.F. Sprague, J.W. Dudley (eds) Corn and corn improvement. American Society of Agronomy, Madison, WI.

Amany A., Bahr M.S., Zeidan, Hozayn M.2006. Yield and quality of maize (Zea mays L.) as affected by slow-release nitrogen in newly reclaimed sandy soil. American-Eurasian J. Agric \& Eviron. Sci. 1: 239-242.

Andrés J.M., Bascialli P.C. 1941. Characteres hereditarios aislaidos en maices cultivados en la Argentina. Univ. Buenos Aires. Fac. Agr.-Vet. 2: 3-26.

Balasubramanian V., Singh L. 1982. Efficiency of nitrogen fertilizer use under rainfed maize and irrigated wheat at Kadawa, northern Nigeria. Fert. Res. 3: 315-324.

B anks W.D., Muir D.D. 1980. Structure and chemistry of the starch granule. [In:] J Press, ed, Biochemistry of Plants, 3. Academic Press, New York: 321-369

B e a r R.P. 1944. Mutations for waxy and sugary endosperm in inbred lines of dent. Agron. J. 36: 89-91.

Blandino M., Reyneri A. 2007. Comparison between normal and waxy maize hybrids for fusarium-toxin contamination in Italy. Maydica 52: 127-134.

Bock A.K., Lheureux K., Libeau-Dulos M., Nilsagard H., Rodriguez-Cerezo E. 2002. Report "Scenarios for co-existence of genetically modified, conventional and organic crops".(IPTS-JRC).

Boonlertnirun, S., Suvannasara R., Boonlertnirun K. 2008. Effects of various nitrogen fertilizer rates and timings of application on yield of waxy corn cv. Big white 852. Agricultural Sci. J. 39 (Suppl.): 294-297.

Boonlertnirun K., Suvarnnasara R. Boonlertnirun S. 2010a. Relationship among leaf greenness, nitrogen content and yield of waxy corn applied with various nitrogen rates. Abstract Book. 3rd Annual International Conference on Agricultural Research .15-18 July 2010,Athens, Greece

Boonlertnirun S., Suvarnnasara R. Suwanas a r a K. 2010b. Yield response of three waxy corn varieties to various nitrogen rates. Kasetsart J. Nat. Sci. 44: 529-535.

B orowiecki J. 1988. Biologiczne aspekty uprawy kukurydzy. / Biological aspects of maize cultivation. Mat. z sesji naukowej pt.: "Stań badań nad agrotechniką kukurydzy w Polsce "IUNG Puławy. 1:9-20. (in Polish)

Braman W.L., Hatfield E.E., Owens F.M., Rincker J.D. 1973. Waxy corn and nitrogen sources for finishing lambs and steers fed all concentrate rations. J. Anim. Sci. 37:1010-1017.

Brink R.A., Macgillnrajy H. 1924. Segregation for the waxy character in maize pollen and differential 
development of the male gametophyte. Amer. Jour. Bot. 11: 465-469.

Brookes G., Barfoot P. 2004. Co-existence in North American agriculture: can GM crops be grown with conventional and agronomic crops? PG Economics Ltd. Raport. Dorchester. UK. 23.

Brown I.L., McNaught K.J., Andrews D., Morita T. 2001. "Resistant Starch: plant breeding, applications, development and commercial uses," in Advanced Dietary Fibre Technology, B. V. McCleary and L. Prosky, Eds., Iowa State University Press, Blackwell Science, Ames, Iowa, USA,

Bure11 M.M. 2003. Starch: the need for improved quality or quantity - an overview. J. Experm. Bot. 54 (382): 451-456.

Chen S.-H., Huang H.-K., Weng D.-H., Lu H.-D. Tong C.-L., Lin X., Rong C. 2003. High-yield population construction and nitrogen feature of new waxy maize combination. Minyunuo. Fujan J. Agric. Sci. 513. (Abstract)

Coe E.H., Neuffer M.G., Hoisington D.A. 1988. The genetics of corn, in Corn and Corn Improvement, chap. 3 - (ed. Sprague, G.F. and Dudley, J.W.) American Society of Agronomy, Madison, WI.

Collin s G.N. 1909. A new type of Indian corn from China. Bur of Plant Ind (Bulletin) 161: 1-30.

Coll in s G.N. 1920. Waxy maize from upper Burma. Science 52 : $48-51$.

Collins N.E., Moran E.T., Stilborn H.L. 2003. Performance of broilers fed normal and waxy corn diets formulated with chick and rooster derived apparent metabolizable energy values for the grains. J. Appl. Poult. Res. 12: 196-206.

Dang N.- C. 2010. Improvement of protein quality in waxy maize (Zea Mays L.) by doubled haploid and marker assisted selection techniques. Thessis. Zurich.

Ding Zhao-hura, Meng Zhao-dong, Hang Fajun, Wang Li-ming, Sun Qi, Hang Qingwei. 2006. General situation and development priority of waxy corn breeding in China. J. Maize. Sci. 513.

Dinn Z.Z., Bird H.R., Sunde M.L. 1982. Nutritional value of waxy corn for chicks. Polutry Sci. 61: 998-1000

Eggum B.O., Dumanović J., Misević D., Denić M. 1985. Nutritive quality and energy yield of high oil, opaque-2 and waxy maize hybrids compared to normal maize hybrids. Plant Foods Hum Nutr. 35: $165-174$

Ertl D., Dale N. 1997. The metabolizable energy of waxy vs. normal corn for poultry. J. Appl. Poultry Res. 6: 432-435.

Felis ia k S. 1987. Słownik biologów polskich. Praca zbiorowa.PAN, PWN, Wa-wa. (in Polish)

Fergas on V. 2001. High amylose and waxy corns: 63-84. In: Specialty Corns. (ed). A.R. Hallauer, Boca Raton, CRS Press:479.
Fotyma E. 1994. Reakcja roślin uprawy polowej na nawożenie azotem.III Kukurydza. / The response of field-grown plants to nitrogen fertilization. Part III. Maize. Fragm. Agron. 4 (44): 20-35 (in Polish).

Gą si orowski H. 2008. Kukurydza. Klasyfikacja, pochodzenie i rozpowszechnienie. / Maize. Classification, origin, and distribution. Przegląd zbożowo-młynarski. 6: 2-4 (in Polish).

Gąs i orowski H. 2005. Kukurydza. Cz. I. Wiadomości ogólne. / Maize. Part I. General information. Przegląd zbożowo-młynarski. 10: 31-33 (in Polish).

Gą si orowski H. 2006. Kukurydza. Cz. XI. Historia kukurydzy w Polsce i na świecie. / Maize. Part XI. The history of maize in Poland and in the world. Przegląd zbożowo-młynarski. 12: 16-18 (in Polish).

Gola chow ski A. 1998. Stosowanie skrobi i jej przetworów w przemyśle spożywczym. / The use of starch and its derivatives in the food industry. Zesz. Nauk. AR Wrocław, Techno. Żywn. 12: 117-124 (in Polish).

Hawton J.D.L., Johnson J., Salzer T.M., Shurs on G.C. 1996. Applications of nutritionally improved corn and soybeans for swine. Pages 263-304 in Proc. $57^{\text {th }}$ Minnesota Nutr. Conf. and Protiva Tech. Symp., Bloomington, Minnesota. Ext. Special Programs. Univ. Minnesota. St. Paul.

Huntington G.B. 1997. Starch utilization by ruminants: from basics to the bunk. J. Anim. Sci. 75: 852-867.

Jin Q.-L., Wang J.-L., Li Z.-H., Cao Y.-Y. 2010. Effect of high planting density of the yield of summer maize. J. Hebei Agric. Sci. Abstact. 562

Johnston L.J., Anderson P.T. 1992. Effect of waxy corn on feedlot performance of crossbred yearling steers:1-5, Minnesota Beef Cattle Research Report.

Jugenheimer R.W. 1976. Corn improvement, seed production, and uses. John Wiley \& Sons, Inc, New York, USA.

K a in u m a K. 1988. Structure and chemistry of the starch granule. [In:] J. Preiss (ed.). The biochemistry of plants, 14. New York: Academic Press: 141-180.

Kimura A., Robyt J.F. 1995. Reaction of enzymes with starch granules; kinetics and products of the reaction with glucoamylase. Carbohydrate Research, 277 (1): 87-107.

K i r b y K.W. 1986. Uses of modified starches in the textile industry, in Modified Starches: Properties and Uses, chap. 14, (ed. Wurzburg, O.B.), CRS Press, Boca Raton, Fl.

Kotarski S.F., Waniska R.D., Thurn K.K. 1992. Starch hydrolysis by the ruminal microflora. J. Nutr. 122: $178-190$.

Kruczek A. 1983. Wpływ nawożenia azotem na plony ziarna kukurydzy w zależności od odmian i gęstości siewu. / The effect of nitrogen fertilization on maize grain yields depending on variety and seeding rate. Pam. Puł. 81: 105-118 (in Polish).

Krysińska P., Gałkowska D., Fortuna T. 2008. Charakterystyka układów skrobi modyfikowanych uzy- 
skanych z kukurydzy woskowej. / Characteristics of modified starch systems obtained from waxy maize. Żywność. Nauka. Technologia. Jakość, 5 (60): 9-23 (in Polish).

La ng m a n R.E. 1986. Uses of modified starches in the food industry in Modified Starches: Properties and Uses, chap. 12, (ed. Wurzburg, O.B.)., CRS Press, Boca Raton, $\mathrm{Fl}$.

Les z c z yń ski W. 2006. Zastosowanie skrobi modyfikowanych w przemyśle spożywczym (cz. I.). / Application of modified starches in the food industry (Part I). Przegl. Piek. Cuk. 5: 54-57 (in Polish).

Lewandowicz G., Mączyński M. 1990. Chemiczna modyfikacja skrobi. Cz. II. Reaktywność skrobi różnych gatunków roślin. / Chemical modification of starch. Part II. Reactivity of starch of various plant species. Chemik, 3: 69-71 (in Polish).

Liu M., Tao H.B., Wang P., Yl Z.X., Lu L.Q., Wang Y. 2009. Effect of sowing date on growth and yield of spring maize. Chinese J. Eco-Agric. (Abstract) 513.

Maher S.L., Cremer C.W. 1993. Uses of modified starches in the paper industry, in Modified Starches: Properties and Uses, chap. 13, (ed. Wurzburg, O.B.)., CRS Press, Boca Raton, Fl.

Michalski T. 1997. Kukurydza jako surowiec dla przemysłu. / Maize as raw material for industry. Zesz. Prob. Post. Nauk Rol. Z. 450: 201-217 (in Polish).

Moore C.D., Tuschoff J.V., Hstings C.W., Schanefelt R.V. 1984. Applications of starch in foods, in starch: chap. 19. Chemistry and technology, $2^{\text {nd }}$ (ed. Whistler, R.L., BeMiller, J.N., Paschall, E.F.), Academic Press, Orlando, Fl.

Musseh1 F.E. 1944. Growth - promoting value of waxy corn for chick. Nebraska Agr. Exp. Sta. Ann. Rep.: 7980 .

Mustafa, M.I., Chadwick, J.P., Akhtar, P., Ali, S., LaTeef, M. \& Sultan, J.I. 2008. The effect of concentrate and silage based finishing diets on the growth performance and carcass characteristics of Suffolk cross and Scottish Blackface lambs. Turk. J. Vet. Anim. Sci. 32 (3), 191-197.

$\mathrm{Ne} 1 \mathrm{~s}$ o n O.E. 1968. The waxy locus in maize. II. The location of the controlling element alleles. Genet. 60: 507-529.

Nocek J.E., Tamminga S. 1991. Site of digestion of starch in the gastrointestinal tract of dairy cows and its effect on milk yield and composition. J. Dairy Sci. 74: 3598-3629.

Nowiński M. 1970. Dzieje upraw i roślin uprawnych. PWRiL, 332 (in Polish).

Oiken S.O., Kling J.G., Okoruwa A.E. 1998. Nitrogen fertilizer management effects on maize grain quality in the West African Moist Savanna. Crop Sci. 38: 1056-1161.

Or E., Boyer S.K., Larkins B.A. 1993. Opaque-2 modifiers act post-transcriptionally and in a polar man- ner on y-zein gene expression in maize endosperm. Plant Cell,5: 1599-1609.

Piekielek W.P., Fox R.H. 1992. Use of chlorphyll meter to predict sidedress nitrogen requirements for maize. Agron J. 84: 59-65.

Ratuszniak E., Kubas A. 2007. Wykorzystanie metody mikroskopowej do badania wielkości ziaren skrobi u różnych gatunków roślin. / The use of the microscopic method to examine the size of starch grains in various plant species. Słupskie Prace Biol. 4: 93-107 (in Polish).

Rohwer R.G., Klem R.E. 1984. Acid-modified starch: Production and uses, in Starch; chap, 17. Chemistry and technology, $2^{\text {nd }}$ (ed. Whistler, R.L., BeMiller, J.N., Paschall, E.F.), Academic Press, Orlando, Fl.

Schopmeyer H.H., Fleton G.E., Ford C.L. 1943. Waxy corn starch as a replacement for tapioca. Ind.Eng. Chem. 35: 1168-1172,

Schroeder J.W., Moon Y.S., Ford J.A., Keller W.L., Park C.S. 1996. Waxy corn as a replacement for dent corn fed in diets of lactating Holstein dairy cows. J. Dairy Sci. 79 (Suppl. 1): 139.

Streeter M.N., Wagner D.G., Owens F.N., Hibb e rd C.A. 1991. The effect of pure and partial yellow endosperm sorghum grain hybrids on site and extent of digestion in beef steers. J. Anim. Sci. 69: 2571-2584.

Tang S.X., Gan J., Sheng L.X., Tan Z.L., Tayo G.O., Sun Z.H., Wang M., Ren G.P. 2008. Morphological fractions, chemical composition and in vitro fermentation characteristics of maize stover of five genotypes. J. Animal, 2 (12): 1772-1779.

Tang S.X., Sheng L.X., Zhou C.S., Tan Z.L., Liao H.Y., Wang M., Sun Z.H., Han X.F., B a mikole M. A. 2009. Effect of variety, sowing season and maturity stages on ruminal phosphorus release from whole maize stover and its morphological fractions. J. Anim. Physiol. Anim. Nutr. 94: 49-58.

Tang S.X., Li F.W., Gan J., Wang M., Zhou C.S., Sun Z.H., Han X.F., Tan Z.L. 2011. Effects of sown season and maturity stage on In vitro fermentation and In sacco degradation characteristics of new variety maize stover. J. Anim. Sci. 24 (6): 781-790.

Tester R.F., Karkalas J. 2001. The effects of environmental conditions on the structural features and physico-chemical properties of starches. Starch 53: 513-519.

Tester R.F., Karkalas J. 2002. Polysaccharides : 381-438. Part II. Polysaccharides from eukaryotes. In: Starch in biopolymers.(ed. Vandamme E.J., De Baets S., Steinbuchel A.), 6. Willey \& Soons.

Tolera A., Sundstol F. 1999. Morphological fractions of maize stover harvested at different stages of grain maturity and nutritive value of different fractions of the stover. Animal Feed Sci. Tech. 81: 1-16.

ValeroJ.A., Maturalno M., Ramirez A., Benito J.M., Alvarez J.F. 2005. Growth and nitrogen use efficiency of irrigated maize in a semiarid region as affected by nitrogen fertilization. Span. J. Agicul. Res. 3 (1): 134-144. 
Va s a 1 S.K. 2001. High quality protein corn: 85-129. In specialty corns (ed. Hallauer A.R.), $2^{\text {nd }}$ CRS Press, Boca Raton, Fl.

Weatherwax P. 1922. A rare carbohydrate in waxy maize. Genet. 7: 568-572.

Weir B.L., Kerby T.A., Hake K.D., Roberts B.A., Zielinski L.J. 1996. Cotton fertility. 210-227. In. Hake S.J., Kerby T.A., Hake K.D. (eds.). Cotton Production Manual. Publ. 3352. Univ. of California, Oakland.

Waligóra H., Dubas A., Swulińska-Katulska A. 1998. Kukurydza cukrowa. Wyd. Multum, Poznań (in Polish).

Waligóra H. 2006. Zbiór i wykorzystanie kukurydzy cukrowej. / Harvest and utilisation of sweet corn. 26-27 Kukurydza Nr 2 (28) (in Polish).

Wałkowski A., Lewandowicz G. 2004. Skrobie modyfikowane właściwości technologiczne i zakres stosowania. / Modified starches: technological properties and the range of application. Przem. Spoż. 5: 49-51 (in Polish).

Xie Y. 2006. Effect of nitrogen application on yield and quality of waxy maize. J. Anhui Agric. Sci.(Abstract) 513.

Young A.H. 1984. In Starch Chemistry and Technology, $2^{\text {nd }}$ edn. Academic Press, New York, USA, 269-283.

Zarate A.J., Morgan T.J., Stilborn H.L. 2004. Comparison of normal dent with waxy, high-oil and waxy-high-oil corns on pellet quality of associated feeds and response by broilers. J. Appl. Poult. Res. 13: 650-659.

Zhao L.Q., Li J.Y., Li W., Su J.S., Xu C.H., Ma Y.K., Zhang Y.B. 2009. Effect of amount of irrigation and fertilizing measures at different growing stage on yield and water use efficiency of maize. J. Jilin Agric. Sci. (Abstract) 513.

\section{Wybrane aspekty \\ uprawy i użytkowania kukurydzy woskowej (Zea mays L. spp. ceratina)}

\section{Streszczenie}

Praca stanowi przegląd dostępnej literatury dotyczącej Zea mays L. ssp. ceratina. Zawiera informacje na temat pochodzenia uprawy i wykorzystania kukurydzy woskowej w świecie i może być przyczynkiem do rozwoju nowych badań z zakresu uprawy i technologii przetwórstwa skrobi.

Kukurydza jako stare i wiodące produkcyjnie zboże odgrywała ogromną rolę w starożytnych cywilizacjach Nowego Świata. Obecnie w Polsce z porównywanych podgatunków kukurydzy największe znaczenie mają Z. mays ssp. indurata oraz Z. mays ssp. indentata. Niewielką pozycję ma podgatunek Z. mays ssp. saccharata, a Z. mays ssp. ceratina nie była dotychczas uprawiana. Decyzje o wprowadzeniu do uprawy podgatunku Z. mays ssp. ceratina są różnorodnej proweniencji, zarówno agroklimatycznej jak i zastosowań przemysłowych produktów uzyskanych z przerobu ziarna. Impulsem do rozwijania badań agrobiologicznych jest rosnący popyt na ziarno kukurydzy, stymulowany zwiększonym zapotrzebowaniem światowego rynku na skrobię i olej kukurydziany, jako surowce mające znaczenie w produkcji żywności. Rozwój przemysłu skrobiowego, związany z zapotrzebowaniem na skrobię przemysłową, przyczyni się zapewne do wzrostu zainteresowania tym podgatunkiem w Europie Środkowej, w tym również w Polsce. Ziarno kukurydzy woskowej może stanowić podstawowy składnik pasz wysokoenergetycznych dla zwierząt gospodarskich, zastępując w tej roli kukurydzę dotychczas uprawianą do tych celów.

Dużym atutem kukurydzy woskowej jest specyficzna budowa skrobi, z uwagi na unikatową i wysoką zawartość amylopektyny (95-98\%), co nadaje nieograniczone możliwości wykorzystania przemysłowego. Obecnie areał kukurydzy woskowej w Europie nie przekracza $2 \%$ powierzchni zasiewów kukurydzy na kontynencie. 